Great interest was aroused at the time, chiefly by reason of the then regarded anomalousness of its habitat, but also by reason of certain other features more or less peculiar, such as the apparent absence of female medusæ, and yet the occurrence of young apparently arising directly from eggs.

It has since been observed in several other localities and under a similar set of conditions, namely, in artificial tanks, or aquaria used for the cultivation of the large water lily, Victoria regia, a native of South America. Records of such occurrence have been made at Lyons and at Munich, in 1901 and 1905 respectively. In all these cases it has appeared and behaved in very much the same way as in London, and the same anomalous disparity of sex has been noted.

The discovery of the medusa, apparently the same species, though on this point $I$ am not yet prepared to state definitely, in this country is naturally, therefore, a matter of some interest to students of animal distribution, and it is the hope of the writer that additional facts bearing upon several of the problems as yet unsolved may be secured. It was a matter of pleasure, therefore, to undertake, with the cooperation of the Bureau of Fisheries, to secure all the data and material which could be had. Thus far only a beginning has been made, and this preliminary notice is only intended to announce the general facts, reserving for a later contribution a fuller and more detailed account of the history of its occurrence. It may be noted in closing that, as in former cases, only male medusæ have been observed. And, furthermore, that no foreign plants have been introduced in these aquaria for several years, and that the Victoria regia has never been grown here.

P. S.-A communication was received by the writer dated September 30, stating that the medusæ had suddenly "disappeared as mysteriously as they came," and that not a single specimen could be found where for weeks they had been abundant.

THE Zoological Laboratory,

$$
\text { Chas. W. Hargitt }
$$

SYracuse UNIVERSITY, September 20, 1907
GAMBUSIA IN NEW JERSEY

Professor John B. Sмith has called attention to the introduction of Gambusia affinis in New Jersey waters as a check to the development of the mosquito, as neither he nor his assistants have met with it in their investigations. It was, therefore, with considerable interest that quite recently Messrs. $\mathrm{H}$. Walker Hand and $\mathrm{O} . \mathrm{H}$. Brown assisted me in finding this little minnow in large numbers in Teal's Branch of Pond Creek, a small tributary of Delaware Bay at Higbee's Beach. We also found it very abundant in New England Creek, another tributary of Delaware Bay just north. There it was associated with large numbers of mostly young or small Fundulus heteroclitus macrolepidotus, Lucania parva, Cyprinodon variegatus, Menidia menidia notata, Eupomotis gibbosus and Palcomonetes vulgaris. The streams mentioned are mainly brackish, though fresh near their headwaters, more or less shallow with muddy bottoms, though with even a clear and gentle current. The males of Gambusia were equally abundant with the females, though the latter were usually larger. The occurrence of Plethodon erythronotus at Higbee's Beach is also interesting.

ACademy of Natural Sciences, Philadelphia, Pa.

\section{COLOR SPORTS AMONG THE INSECTS}

In the August 16 number of ScIence Mr. A. Franklin Shull puts on record the occurrence of a pink katydid, Amblycorypha oblongifolia DeG., which was taken near Detroit, Mich., on August 12, and he invites others to place on record their captures of similarly colored insects. Professor J. B. Smith has, in years past, taken several pink katydids in the pine barrens of southern New Jersey, and on August 1 of the current year I took a male specimen of the above species at Lahaway, Ocean County, New Jersey. None of Professor Smith's specimens retained their delicate color more than a few weeks at most and the Lahaway example lost most of its pink color in about two weeks, though the head, pronotum, wing veins and parts of the legs are up to this date still a decided pink. The 